\title{
Chemical quality of raw milk as influenced by stages of lactation of crossbred cows
}

\author{
NAVDEEP SINGH AND U.K. SHUKLA
}

\begin{abstract}
A study was conducted at Chitrakoot-Satna (M.P.) and Smriti Products (Pvt.) Ltd., Saha, Ambala (Haryana), during April to June 2014 to determine the chemical quality of raw milk as influenced by stages of lactation of crossbred cows. The objective was to evaluate the compositional quality of raw milk of different crossbred cows. Ten healthy cows, free from any disease, and maintained under similar management conditions, were selected for the study. All sanitary precautions were undertaken to produce clean milk. The samples of raw milk collected from time to time, were tested to determine total solid ( \%), fat ( \%), solid not fat ( \%), protein ( \%), lactose ( \%), ash ( \%), specific gravity (cc), and water ( \%). The data obtained for the aforesaid tests were subjected to statistical analysis. The results of the statistical analysis showed that the differences in TS, fat. SNF, protein, lactose, ash and water of raw milk were non-significant and the results of F-test were also found non-significant due to stages of lactation. Only specific gravity was significant. Therefore, the chemical quality of raw milk of crossbred cows was not influenced by stages of lactation. The results further indicated that compositional quality of raw milk of third lactation stage $\left(\mathrm{S}_{3}\right)$ was best followed by second $\left(\mathrm{S}_{2}\right)$ and first $\left(\mathrm{S}_{1}\right)$ stages of lactation.
\end{abstract}

KEY WORDS : Raw milk, Chemical quality, Stages of lactation, Crossbred cows

How TO CITE THIS PAPER : Singh, Navdeep and Shukla, U.K. (2014). Chemical quality of raw milk as influenced by stages of lactation of crossbred cows. Res. J. Animal Hus. \& Dairy Sci., 5(2) : 102-104.

Address for correspondence :

Navdeep Singh, Department of Natural Resource Management, Faculty of Agriculture, Mahatma Gandhi Chitrakoot Gramodaya Vishwavidyalaya, Chitrakoot, SATNA (M.P.) INDIA

Email : ndsinghbhadoriya@gmail.com

Associated Authors':

U.K. Shukla, Department of Natural Resource Management, Faculty of Agriculture, Mahatma Gandhi Chitrakoot Gramodaya Vishwavidyalaya, Chitrakoot, SATNA (M.P.) INDIA

Email : umeshdr_2006@rediffmail.com 